\title{
Anti Bacterial Activity of Dashapushpa Ghritham
}

\author{
Sreedevy K, Praseetha P.K
}

\begin{abstract}
Dashapushpam is a group of ten sacred plants famous for its cultural and medicinal properties and it is used by the people of Kerala, specially during the monsoon season. This study is to demonstrate the anti bacterial activity of the ten herbs when used as a drug called dashapushpa ghritham. The anti bacterial activity was evaluated against the bacterial strains pseudomonas aerugenosa and bacillus cereus by agar-gel diffusion method. All the extract showed various level of activity for this test organisms and their activity is compared with the standard antibiotic. This study shows that the drug has significant activity than the base and individual plant extract. This result encourages the studies for the significant usage of the ten herbs in various medicines used as anti-infective agent.
\end{abstract}

Keywords-Dashapushpa ghritham, antibacterial activity, agar-gel diffusion method.

\section{INTRODUCTION}

Microbial infections are always a threat to the mankind $[1,2,3]$. The frequency and the novelty of such infections have increased in the recent years worldwide. The infectious microorganisms developed resistance towards the synthetic antibiotic due to their prolonged usage $[4,5,6]$. This marks the significance of developing natural drugs using plant extracts. Such medicinal formulations are also free from side effects and safe to use due to their organic origin[7,8,9]. Dashapushpam are a cluster of ten different herbs namely Aerva lanata (L) Juss, Biophytum sensitivum(L.) DC, Cardiospermum halicacabum (Linn.), Curculigo orchioides Gaertn, Cynodon dactylon (Pers.), Eclipta alba (L.) Hassk., Emilia sonchifolia (L.) DC, Evolvulus alsinoides (Linn.) Linnv, Ipomoea sepiaria Roxb., Vernonia cinerea L $[10,11,12,13,14]$. They have various medicinal properties including anti-diabetic, anti-cancer, anti-tumor, hepatoprotective, immunomodulatory, anti-diarrheal, anti-helminthic, anti-inflammatory, antioxidant and anti-microbial activity[15,16,17,18].The different properties of dashapushpam plants are shown in table $1[19,20,21,22]$.The present study is to investigate the anti bacterial activity of these plants extract and the drug dashapushpa ghritham when tested against gram positive and gram negative bacteria[23,24,25]. Dashapushpa ghritham is a drug formulation from an ancient ayurvedic text "visha vaidhya jyostnika". The drug contains the aqueous extract of ten sacred plants with the base like ghee, sandal etc $[26,27,28,29,30]$.

Revised Manuscript Received on October 25, 2019.

Sreedevy $\mathbf{K}^{\mathbf{1}}$, Department of Department of Nanotechnology, Noorul Islam Centre for Higher Education, Kumaracoil, Thuckalay.

Praseetha P. K*, Department of Nanotechnology, Noorul Islam Centre for Higher Education, Kumaracoil, Thuckalay,

Corresponding Email: crkpkp@gmail.com

\section{MATERIALS AND METHODS}

\section{A. PLANT MATERIAL}

The ten sacred plants dashapushpam was collected from various parts of malappuram district, Kerala, India. The plants were washed in tap water, shade dried and powdered. B . EXTRACTION PREPARATION

The plants were cleaned and shade dried. $50 \mathrm{~g}$ of powdered sample was added to $300 \mathrm{ml}$ distilled water and heated for 15 min with continuous stirring. Then the extract was cooled at room temperature for $24 \mathrm{hrs}$. 
Anti Bacterial Activity of Dashapushpa Ghritham

Table.1 Plant based studies

\begin{tabular}{|c|c|c|c|c|c|c|c|c|c|c|c|c|c|}
\hline $\begin{array}{l}\text { Sl } \\
\text { no }\end{array}$ & $\begin{array}{l}\text { Botanical } \\
\text { name of } \\
\text { the herb }\end{array}$ & $\begin{array}{l}\text { Anti- } \\
\text { bacte } \\
\text { rial } \\
\text { activ } \\
\text { ity }\end{array}$ & $\begin{array}{c}\text { Ant } \\
\text { i-ox } \\
\text { idan } \\
t \\
\text { acti } \\
\text { vity }\end{array}$ & $\begin{array}{c}\text { Hepat } \\
0 \\
\text { protec } \\
\text { tive } \\
\text { activit } \\
y\end{array}$ & $\begin{array}{c}\text { Ant } \\
\text { i-tu } \\
\text { mou } \\
r \\
\text { acti } \\
\text { vity }\end{array}$ & $\begin{array}{c}\text { Diur } \\
\text { etic } \\
\text { activ } \\
\text { ity }\end{array}$ & $\begin{array}{c}\text { Ant } \\
\text { i-py } \\
\text { reti } \\
\text { c } \\
\text { acti } \\
\text { vity }\end{array}$ & $\begin{array}{c}\text { Anti-infla } \\
\text { mmatory } \\
\text { activity }\end{array}$ & $\begin{array}{l}\text { Ant } \\
\text { i-fu } \\
\text { ngal } \\
\text { acti } \\
\text { vity }\end{array}$ & $\begin{array}{c}\text { Ant } \\
\text { i-C } \\
\text { anc } \\
\text { er }\end{array}$ & $\begin{array}{c}\text { Anti } \\
\text {-dia } \\
\text { beti } \\
\text { c }\end{array}$ & $\begin{array}{c}\text { Wou } \\
\text { nd } \\
\text { Heal } \\
\text { ing }\end{array}$ & $\begin{array}{l}\text { Re } \\
\text { f : }\end{array}$ \\
\hline 1 & $\begin{array}{c}\text { Aerva } \\
\text { lanata (L) } \\
\text { Juss. }\end{array}$ & + & + & + & + & + & & + & + & + & + & & $\begin{array}{l}4,9 \\
, 10\end{array}$ \\
\hline 2 & $\begin{array}{l}\text { Biophytu } \\
\text { m } \\
\text { sensitivu } \\
\text { m (L.) } \\
\text { DC. }\end{array}$ & + & + & + & + & + & & + & + & + & + & + & $\begin{array}{l}1, \\
11, \\
12\end{array}$ \\
\hline 3 & $\begin{array}{l}\text { Cardiosp } \\
\text { ermum } \\
\text { halicacab } \\
\text { um } \\
\text { (Linn.) }\end{array}$ & + & + & & + & & + & + & + & & + & + & $\begin{array}{l}13, \\
14, \\
15\end{array}$ \\
\hline 4 & $\begin{array}{l}\text { Curculigo } \\
\text { orchioide } \\
\text { s Gaertn. }\end{array}$ & + & + & & & & + & + & + & + & + & + & 16 \\
\hline 5 & $\begin{array}{l}\text { Cynodon } \\
\text { dactylon } \\
\text { (Pers.) }\end{array}$ & & & & & & & & & + & + & & $\begin{array}{l}17, \\
18\end{array}$ \\
\hline 6 & $\begin{array}{c}\text { Eclipta } \\
\text { alba (L.) } \\
\text { Hassk. }\end{array}$ & + & + & & & + & & + & + & & & + & $\begin{array}{l}19, \\
20\end{array}$ \\
\hline 7 & $\begin{array}{c}\text { Emilia } \\
\text { sonchifoli } \\
\text { a (L.) DC. }\end{array}$ & + & + & + & & & & + & & + & + & + & $\begin{array}{l}21, \\
22\end{array}$ \\
\hline 8 & $\begin{array}{l}\text { Evolvulu } \\
\text { s } \\
\text { alsinoides } \\
\text { (Linn.) } \\
\text { Linn. }\end{array}$ & + & + & + & & & & + & + & + & + & + & $\begin{array}{l}23, \\
24\end{array}$ \\
\hline 9 & $\begin{array}{c}\text { Ipomoea } \\
\text { sepiaria } \\
\text { Ro+b. }\end{array}$ & + & + & & & & & & & & & + & $\begin{array}{l}25, \\
26\end{array}$ \\
\hline 10 & $\begin{array}{l}\text { Vernonia } \\
\text { cinerea L. }\end{array}$ & + & & & & & & & + & & & + & $\begin{array}{l}27, \\
28\end{array}$ \\
\hline
\end{tabular}

The solution was filtered using whatman filter paper [no.1] using vaccum pump. The filtrate was concentrated at $40^{\circ} \mathrm{c}$ until solvents evaporated completely. The sample was dissolved in sterile distilled water [6].

\section{C.DRUG PREPARATION}

The method of preparation of drug is based on the ayurvedic text Vishavaidhya jyostnika in connection with viper venom and non-healing ulcers.

\section{D.MICRO ORGANISAMS USED}

Gram negative bacteria used was Pseudomonas aerogenosa and gram positive was bacillus cereus.

\section{E.ANTI BACTERIAL ACTIVITY}

Anti-bacterial activity of the plant extract was evaluated by agar-gel diffusion method. Nutrient agar plates were prepared and $1 \mathrm{ml}$ of each bacterial suspension was evenly spread on the solidified 
$20 \mathrm{ml}$ nutrient agar plate. Plate had three well of $6 \mathrm{~mm}$ diameter cut out in it. Sample was added in the first well, positive control (Amoxillin 30 $\mathrm{g} / \mathrm{ml}$ ) in the second and negative control (sterile distilled water) in the third. $20 \mu \mathrm{l}$ of $0.5 \mathrm{~g} / \mathrm{ml}$ plant extract was added into one gram positive and one gram negative plate. The dashapushpa ghritham was also added to a well on both gram positive and gram negative bacterial culture plate with positive and negative control. The base (drug excluding the plant extract) was also tested in the similar way for its anti-bacterial activity. The plates were incubated at $37^{\circ} \mathrm{c}$ for 2-3 days. Zone of inhibition was observed around the sample well and the positive control. Diameter of the zone was measured.

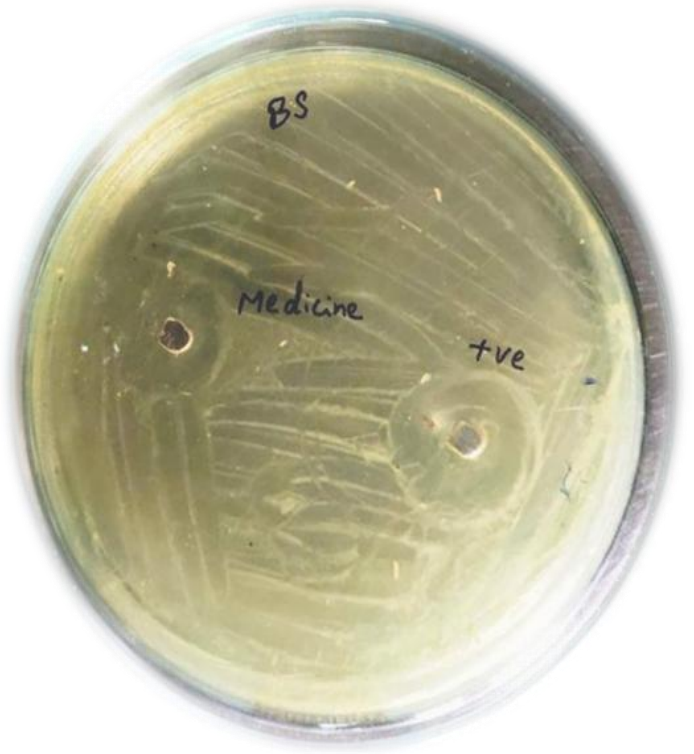

Fig .2 Dashapushpa ghritham (Medicine) and Positive control amoxilin.

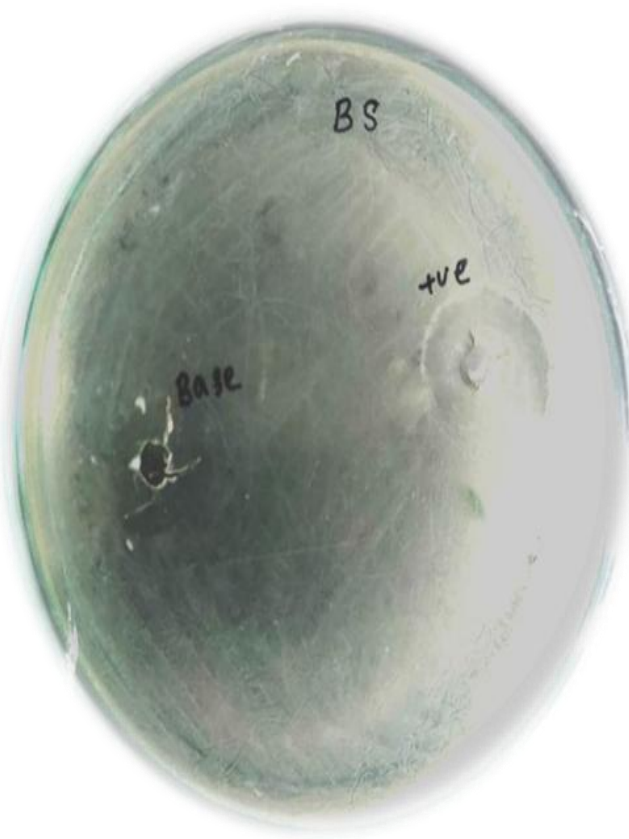

Fig .3 Base and positive control amoxillin

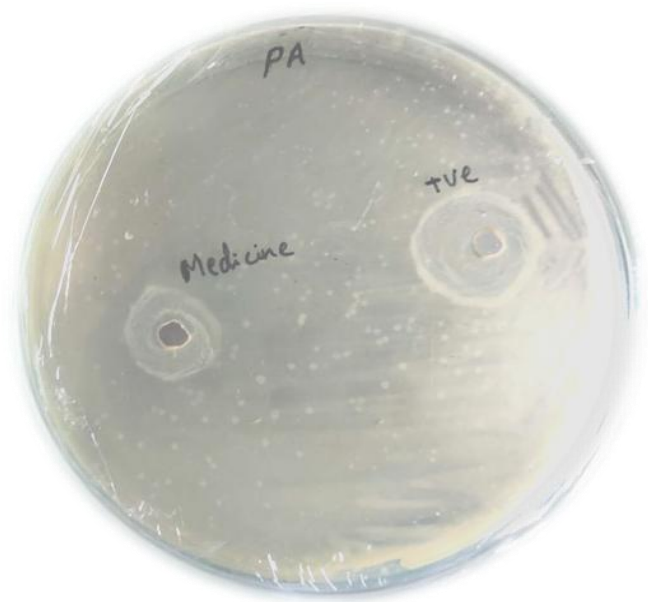

Fig .4 Dashapushpa ghritham and Positive control amoxillin

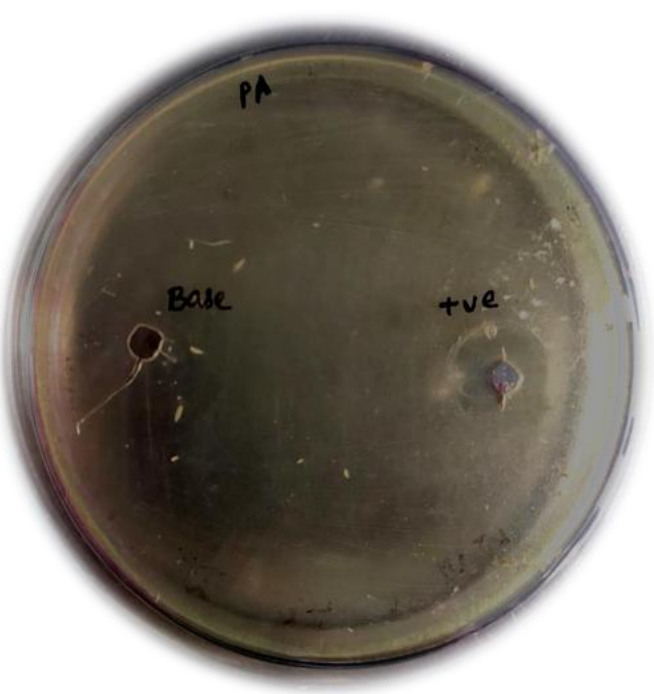

Fig .5 Base and positive control amoxillin

\section{RESULTS AND DISCUSSION}

The results for the antimicrobial activity by agar-gel diffusion method are presented in table 2. All the members of dashapushpam showed various range of antibacterial activity with pseudomonas aerugenosa and bacillus cereus. Positive control amoxilin gave $1.7 \mathrm{~cm}$ diameter of inhibition zone with pseudomonas and $1.8 \mathrm{~cm}$ diameter of inhibition zone with bacillus cereus. Negative control distilled water does not have any zone of inhibition. Among the individual plant extracts ipomea sepiaria showed maximum anti bacterial activity with zone of inhibition of $1.8 \mathrm{~cm}$ diameter for both gram negative and gram positive organisms. This value is same as that of the positive control amoxillin. Least activity was observed in evolvulus alsinoides with a diameter of 0.9 $\mathrm{cm}$ and $1.2 \mathrm{~cm}$ with gram negative and gram positive bacteria respectively. All other plant extracts ranges between these values. The drug dashapushpa ghritham showed $1.5 \mathrm{~cm}$ diameter zone of inhibition with gram positive and $1.7 \mathrm{~cm}$ with gram negative bacteria. The base of the drug without the plant extract also had some antibacterial activity. The base had $0.7 \mathrm{~cm}$ diameter of zone of inhibition with both gram positive and negative organisms.

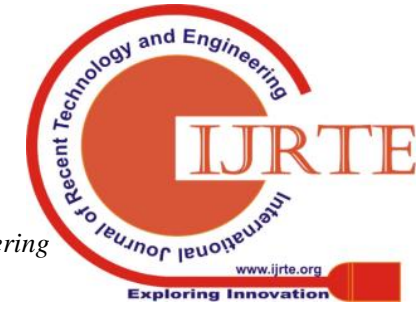


Anti Bacterial Activity of Dashapushpa Ghritham

Table .2 Antibacterial activity of dashapushpa Ghritham Vs individual

\begin{tabular}{|c|c|c|c|c|c|}
\hline \multirow{2}{*}{$\begin{array}{l}\text { Sl } \\
\text { no }\end{array}$} & \multirow[b]{2}{*}{ Scientific Name } & \multirow[b]{2}{*}{ Bacteria } & \multicolumn{3}{|c|}{ Diameter of inhibition Zone } \\
\hline & & & Sample & $\begin{array}{l}\text { Positive } \\
\text { control }\end{array}$ & $\begin{array}{c}\text { Negative } \\
\text { control }\end{array}$ \\
\hline \multirow{2}{*}{1} & \multirow{2}{*}{ Aerva laneta } & $\mathrm{Gm}$-ve & $1.6 \mathrm{~cm}$ & $1.7 \mathrm{~cm}$ & 0 \\
\hline & & $\mathrm{Gm}+\mathrm{ve}$ & $1 \mathrm{~cm}$ & $1.8 \mathrm{~cm}$ & 0 \\
\hline \multirow{2}{*}{2} & \multirow{2}{*}{ Biophytum sensitivum } & $\mathrm{Gm}$-ve & $1.2 \mathrm{~cm}$ & $1.7 \mathrm{~cm}$ & 0 \\
\hline & & $\mathrm{Gm}+\mathrm{ve}$ & $1.3 \mathrm{~cm}$ & $1.8 \mathrm{~cm}$ & 0 \\
\hline \multirow{2}{*}{3} & \multirow{2}{*}{ Cardiospermum halicabum } & $\mathrm{Gm}$-ve & $1.1 \mathrm{~cm}$ & $1.7 \mathrm{~cm}$ & 0 \\
\hline & & $\mathrm{Gm}+\mathrm{ve}$ & $1.4 \mathrm{~cm}$ & $1.8 \mathrm{~cm}$ & 0 \\
\hline \multirow{2}{*}{4} & \multirow{2}{*}{ Curculigo orchoid } & Gm-ve & $1.1 \mathrm{~cm}$ & $1.7 \mathrm{~cm}$ & 0 \\
\hline & & $\mathrm{Gm}+\mathrm{ve}$ & $1.2 \mathrm{~cm}$ & $1.8 \mathrm{~cm}$ & 0 \\
\hline \multirow{2}{*}{5} & \multirow{2}{*}{ Cynodon dactlyon } & Gm-ve & $1.2 \mathrm{~cm}$ & $1.7 \mathrm{~cm}$ & 0 \\
\hline & & $\mathrm{Gm}+\mathrm{ve}$ & $1 \mathrm{~cm}$ & $1.8 \mathrm{~cm}$ & 0 \\
\hline \multirow{2}{*}{6} & \multirow{2}{*}{ Eclipta alba } & Gm-ve & $1.1 \mathrm{~cm}$ & $1.7 \mathrm{~cm}$ & 0 \\
\hline & & $\mathrm{Gm}+\mathrm{ve}$ & $1.4 \mathrm{~cm}$ & $1.8 \mathrm{~cm}$ & 0 \\
\hline \multirow{2}{*}{7} & \multirow{2}{*}{ Emilia sonchifolia } & $\mathrm{Gm}$-ve & $1.5 \mathrm{~cm}$ & $1.7 \mathrm{~cm}$ & 0 \\
\hline & & $\mathrm{Gm}+\mathrm{ve}$ & $1.5 \mathrm{~cm}$ & $1.8 \mathrm{~cm}$ & 0 \\
\hline \multirow{2}{*}{8} & \multirow{2}{*}{ Evolvulus alsinoides } & Gm-ve & $0.9 \mathrm{~cm}$ & $1.7 \mathrm{~cm}$ & 0 \\
\hline & & $\mathrm{Gm}+\mathrm{ve}$ & $1.2 \mathrm{~cm}$ & $1.8 \mathrm{~cm}$ & 0 \\
\hline \multirow{2}{*}{9} & \multirow{2}{*}{ Ipomea sepiaria } & Gm-ve & $1.8 \mathrm{~cm}$ & $1.7 \mathrm{~cm}$ & 0 \\
\hline & & $\mathrm{Gm}+\mathrm{ve}$ & $1.8 \mathrm{~cm}$ & $1.8 \mathrm{~cm}$ & 0 \\
\hline \multirow{2}{*}{10} & \multirow{2}{*}{ Vernonia cineirea } & Gm-ve & $1.3 \mathrm{~cm}$ & $1.7 \mathrm{~cm}$ & 0 \\
\hline & & $\mathrm{Gm}+\mathrm{ve}$ & $1.6 \mathrm{~cm}$ & $1.8 \mathrm{~cm}$ & 0 \\
\hline \multirow{2}{*}{11} & \multirow{2}{*}{ Dashapushpam } & $\mathrm{Gm}$-ve & $1.3 \mathrm{~cm}$ & $1.7 \mathrm{~cm}$ & 0 \\
\hline & & $\mathrm{Gm}+\mathrm{ve}$ & $1.5 \mathrm{~cm}$ & $1.8 \mathrm{~cm}$ & 0 \\
\hline \multirow{2}{*}{12} & \multirow[b]{2}{*}{ Dashapushpa Ghritham } & Gm-ve & $1.7 \mathrm{~cm}$ & $1.7 \mathrm{~cm}$ & 0 \\
\hline & & $\mathrm{Gm}+\mathrm{ve}$ & $1.5 \mathrm{~cm}$ & $1.8 \mathrm{~cm}$ & 0 \\
\hline \multirow{2}{*}{13} & \multirow{2}{*}{ Base } & $\mathrm{Gm}$-ve & $0.7 \mathrm{~cm}$ & $1.7 \mathrm{~cm}$ & 0 \\
\hline & & $\mathrm{Gm}+\mathrm{ve}$ & $0.7 \mathrm{~cm}$ & $1.8 \mathrm{~cm}$ & 0 \\
\hline
\end{tabular}

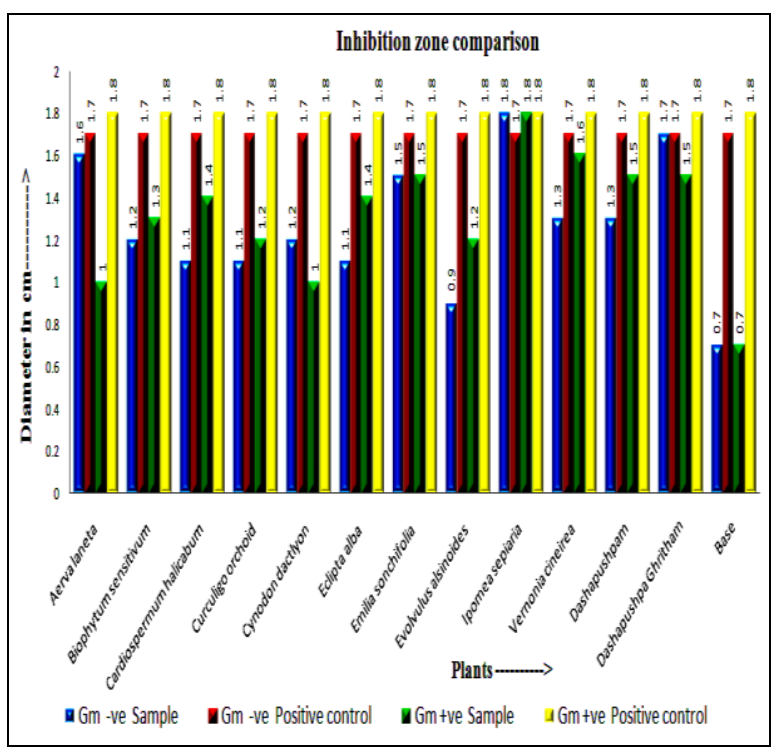

Fig .6 Inhibition zone comparison

\section{CONCLUSION}

From the above results, it is observed that the ten plant extracts when used together in a drug has significant anti bacterial property than most of the other individual plant extracts. In the case of gram negative organisms the drug has similar activity of the positive control antibiotic amoxilin. Further investigations can highlight the potentiality of the drug. Phytochemical studies are required to isolate the type of compound responsible for the antimicrobial activity. This study also encourages the use of dashapushpam for different medicinal formulations. . The investigation ensures the use of herbal extracts as therapeutic agents against pathogenic micro organisms.

The discovery of natural remedy for bacterial infection would be a great achievement for the modern medicine 


\section{REFERENCES}

1. D. Natarajan, M.S. Shivakumar, Srinivasan; "Antibacterial activity of leaf extract of Biophytum sensitivum”, Journal of pharmaceutical sciences and research,2010, vol 2(11),717

2. Al-Bari M.A.A., Sayeed M.A., Rahman M.S. "Characterization and antimicrobial activities of extracts in a phenolic acid derivative produced by Streptomyces bangladeshiensis, a novel species collected in Bangladesh". Res. J. Med. and Med. Sci., 2006, 1: 77-81.

3. K. Jiny Varghese, J. Anila, R. Nagalekshmi, S. Resiya and J. Sonu, Dasapushpam: "The Traditional Uses And The Therapeutic Potential Of Ten Sacred Plants Of Kerala State In India”, IJPSR, 2010; Vol. 1(10): 50-59 ISSN: 0975-8232

4. Mandal, Bitasta \& Madan, Swati. (2015). "Aerva lanata: A Blessing of Mother Nature”, Journal of Pharmacognosy and Phytochemistry. 5. 92-101.

5. "Vishavaidya jyostnika", an ayurvedic medicinal book Sixth chapter (Adikaram), Mandali visham (Vipervenam) Non healing ulcers

6. Parekh J, Chanda S. "In-vitro Antimicrobial Activities of Extracts of Launaea procumbens Roxb. (Labiateae), Vitis vinifera L. (Vitaceae) and Cyperus rotundus L. (Cyperaceae)". African Journal of Biomedical Research. 2006; 9(2):89-93

7. Arun Raj Gr, Shailaja U, Rao Prasanna N, Ajayan S, "The therapeutic potential of ten sacred plants (dashapushpam) of kerala state of southern india ",Journal of Ayurveda and Holistic Medicine, |July 2013, Vol 1,Issue 3

8. Vijayan Mini N, Barreto Ida, Dessai Seema, Dhuri Shital, D’ Silva Riva and Rodrigues Astrida, "Antimicrobial activity of ten common herbs, commonly known as 'Dashapushpam' from Kerala, India”, African Journal of Microbiology Research Vol. 4(22) pp. 2357-2362, 18 November, 2010

9. Indira Priya Darsini. A. "Evaluation of antimicrobial activity of Aerva lanata along with preliminary phytochemical screening." Int $\begin{array}{llll}\text { Res. J. } & \text { Pharm. } & \text { 2015; } & \text { 374-376 }\end{array}$ http://dx.doi.org/10.7897/2230-8407.06677.

10. Payal C, Gurlaganjeet K, Davinder K, Gagan S, Amit C, et al. (2015) "A Review on Phytochemistry and Biological Activities of Aerva." Med Aromat Plants 4: 187. doi:10.4172/2167-0412.1000187

11. B. Saritha1 and P. Brindha "Wound healing potential of Biophytum sensitivum (L.) DC.: An ayurvedic drug", Journal of Chemical and Pharmaceutical Research, 2015, 7(3):87-94

12. A.T. Pawar, and N. S. Vyawahare, " phytochemical and pharmacological profile of biophytum sensitivum (l) $d c$ ", Int J Pharm Pharm Sci, Vol 6, Issue 11, 2014 page

13. Stalin.C, Vivekanandan.K \& Bhavya.E, "In Vitro Antidiabetic Activity of Cardiospermum Halicacabum leaves Extracts", Global Journal of Medical Research, Volume 13 Issue 7 Version 1.0 Year 2013.

14. S. N. Suresh, S. Rathishkumar, V. Rajeshwari, P. Sagadevan, S. Gayathri and D. Vithya Eswari, "Phytochemical analysis and antibacterial potential of Cardiospermum halicacabum Linn. (Sapindaceae)”, Int. J. of Pharm. \& Life Sci. (IJPLS), Vol. 3, Issue 12: December: 2012,

15. Syed Atif Raza, Shahzad Hussain, Humayun Riaz and Sidra Mahmood, " Review of beneficial and remedial aspects of Cardiospermum halicacabum L. ", Afr. J. Pharm. Pharmacol, Vol. 7(48), pp. 3026-3033, 29 December, 2013

16. Saba irshad, J Singh, S P Jain and S P S Khanuja, "Curculigo orchioides Gaertn (Kali musali) An endangered medicinal plant of commercial value”, Naturl product Radiance, vol 5,2006, pp 369-372

17. Kartikey Pandey, C. S. Singh, Raj K. Prasad, A. K. Singh and M. K. Mishra, "Studies of anti-microbial activity using leaf extract of Cynodon dactylon", Scholars Research Library Der Pharmacia Lettre, 2016, 8 (3):325-330

18. Das Mukesh Chandra1, Shilpi Shama2, Chandra Satish3, “ overview of cynodon dactylon (doob grass) in modern medicine as antidiabetic herb ", Journal of Drug Delivery \& Therapeutics; 2013 , 3(6), 117-120

19. Ayodhya Singh, Anjali Singh, Vandana Dwivedi, "Antidiabetic effect of Eclipta alba", International Journal of Scientific \& Engineering Research, Volume 5, Issue 2, February-2014, pp1462-1466

20. Dharmender Jaglan, Amandeep singh Brar \& Rupamjot Gill, "Pharmacological Activity and Chemical Constituents of Eclipta Alba”, Volume 13 Issue 7 Version 1.0 Year 2013, pp34-40
21. Dash Gouri Kumar, Abdulla Mohd, Syafiq and Yahaya Ruhaiyem, "Traditional uses, phytochemical and pharmathological aspects of emilia sonchifolia(l.),Dc”, Int. J. Res Ayurveda Pharm, 2015; 6(4): 551-556

22. Dominic sophia, Paramasiva Ragavendran, Chinthamony Arul Raj, Velliyur Kanniapan Gopalakrishnan, "Antioxident properties of Emilia sonchifolia(L): An in vitro study”, Journal of pharmacy research 2012,5(2),1162-1164.

23. Lekshmi Gangadhar and P. K. Praseetha, A Novel Modeling of Quantum Dot Sensitized Solar cells, Journal of Computational and Theoretical Nanoscience. 2019, Vol. 16, 389-392.

24. Lekshmi Gangadhar, Anusha Kannan and P. K. Praseetha ,Quantum Dot-Sensitized Solar Cells Via Integrated Experimental And Modeling Study, Journal of Computational and Theoretical Nanoscience, 2019, Vol. 16, 436-440.

25. Lekshmi Gangadhar, Akhila Rajan, P. K Praseetha, Semiconductor Quantum Dots for Performance Improvement in Solar Cells, International Journal of Recent Technology and Engineering, 2019, Vol. 7, 11-17.

26. Amritpal Singh, "Review of Ethnomedicinal Uses and Pharmacology of Evolvulus alsinoides Linn." Ethnobotanical Leaflets 12: 734-40. 2008 , 